\title{
Lactobacillus hordei sp. nov., a bacteriocinogenic strain isolated from malted barley
}

Correspondence

Douwe van Sinderen

d.vansinderen@ucc.ie

\section{Susan Rouse, ${ }^{1}$ Carlos Canchaya ${ }^{2}$ and Douwe van Sinderen ${ }^{1,2}$}

\author{
${ }^{1}$ Department of Microbiology, National University of Ireland, Western Road, Cork, Ireland \\ ${ }^{2}$ Alimentary Pharmabiotic Centre, Biosciences Institute, National University of Ireland, Western \\ Road, Cork, Ireland
}

\begin{abstract}
A high-throughput screening effort, designed to isolate bacteriocin-producing lactic acid bacteria (LAB) from malted cereals, resulted in the isolation of four bacteriocin-producing strains that could not be assigned conclusively to recognized species. The four isolates (UCC128 ${ }^{\top}$, UCC125, UCC126 and UCC127) were found to share identical (100\%) 16S rRNA gene sequences and were therefore deemed to belong to the same species. The strains were Grampositive, catalase-negative, non-motile homofermentative $L A B$. The closest recognized relative to strain UCC $128^{\top}$ identified based on comparative $16 \mathrm{~S}$ rRNA gene sequence analysis was Lactobacillus mali DSM $20444^{\top}$ ( $97 \%$ similarity). The strains were characterized phenotypically to identify specific growth requirements. DNA-DNA hybridization between strain UCC128 ${ }^{\top}$ and L. mali DSM $20444^{\top}$ revealed a level of relatedness of only $39.4 \%$. This indicates that strain UCC1 $28^{\top}$ does not belong to the species $L$. mali. The four bacteriocin-producing strains are therefore considered to represent a novel species of the genus Lactobacillus, for which the name Lactobacillus hordei sp. nov. is proposed. The type strain is UCC128 ${ }^{\top}\left(=\mathrm{DSM} 19519^{\top}=\mathrm{LMG}\right.$ $24241^{\top}$ ).
\end{abstract}

Barley is a natural habitat for lactic acid bacteria (LAB) (O’Mahony et al., 2000; Hartnett et al., 2002). The numbers of LAB on barley have been shown to increase as a result of the malting process during brewing (O'Sullivan et al., 1999), possibly because the steeping conditions create a favourable environment for their growth. However, LAB counts start to decrease during barley germination and continue to decline throughout the kilning process (O’Sullivan et al., 1999). A screening project was undertaken to isolate bacteriocin-producing LAB from malted barley by means of a high-throughput approach with an automated colony-picker (Genetix) (Rouse et al., 2007). In total, the screening process yielded approximately 77798 LAB colonies, all of which were assayed for bacteriocin production. Of these, $179 \mathrm{LAB}$ were shown to possess bactericidal activity and were selected for further investigation. Strain UCC128 ${ }^{\mathrm{T}}$, which was shown to possess bactericidal activity, could not be assigned to a definite species grouping on the basis of initial 16S rRNA

Abbreviation: $L A B$, lactic acid bacteria.

The GenBank/EMBL/DDBJ accession number for the 16S rRNA gene sequence of strain UCC $128^{\top}$ is EU074850.

Phylogenetic trees showing the relationship between strain UCC $128^{\top}$ and related species of the genus Lactobacillus based on 16S rRNA gene sequences, constructed with the maximum-parsimony and maximum-likelihood methods, are available with the online version of this paper. gene sequencing. Three other bacteriocin-producing strains were isolated in the same way, all of which had 16S rRNA gene sequences that were identical to that of isolate UCC $128^{\mathrm{T}}$. This study describes the phenotypic and genotypic characterization of these isolates, which are shown to represent a novel species of the genus Lactobacillus.

Strains UCC128 ${ }^{\mathrm{T}}$, UCC125, UCC126 and UCC127 were isolated from malted barley obtained from a brewing facility in Belgium. The four cultures were routinely grown in MRS broth (Oxoid) at $30{ }^{\circ} \mathrm{C}$ for $16 \mathrm{~h}$ and maintained in $40 \%$ glycerol at $-80{ }^{\circ} \mathrm{C}$. The purity of the cultures was checked by streaking them on MRS agar (Oxoid), incubating them anaerobically at $30{ }^{\circ} \mathrm{C}$ for $16 \mathrm{~h}$ and observation under a microscope. Reference strain Lactobacillus mali DSM $20444^{\mathrm{T}}$ was grown according to the instructions outlined by the DSMZ (Deutsche Sammlung von Mikroorganismen und Zellkulturen, Braunschweig, Germany). Cell morphology was examined by streaking on MRS agar and incubating the plates at $30{ }^{\circ} \mathrm{C}$ anaerobically for 3 days. Overnight cultures grown in MRS broth were viewed by using phase-contrast microscopy (Leica DMLS). Strains UCC128 ${ }^{\mathrm{T}}$, UCC125, UCC126 and UCC127 were subjected to phenotypic characterization. The Gram reaction was determined by Gram staining as described by Hucker (1921). Carbohydrate fermentation profiles were determined by 
using an API 50CH test kit (bioMérieux). Catalase activity was investigated by adding $5 \% \mathrm{H}_{2} \mathrm{O}_{2}$ to fresh colonies from MRS agar and examining for the production of $\mathrm{O}_{2}$ bubbles. Growth at temperatures between 15 and $45{ }^{\circ} \mathrm{C}$ was examined in addition to the ability to grow between $\mathrm{pH} 3$ and 9. Gas production from glucose was determined by growing the isolates overnight in MRS broth sealed with $2 \%$ sterile molten agar. Tolerance to salt was tested by growing the isolates in MRS broth and on MRS agar containing $1-10 \% \mathrm{NaCl}(\mathrm{w} / \mathrm{v})$, followed by incubation at $30{ }^{\circ} \mathrm{C}$ for 3 days. Sensitivity of the isolates to antibiotics was tested by placing discs containing the different antibiotics (Oxoid) on the surface of MRS agar, onto which the cultures had been spread-plated. Ampicillin $(25 \mu \mathrm{g})$, penicillin $(2 \mathrm{U})$, metronidazole $(5 \mu \mathrm{g})$, amoxicillin $(30 \mu \mathrm{g})$, trimethoprim $(5 \mu \mathrm{g})$, chloramphenicol $(30 \mu \mathrm{g})$, cephradine $(30 \mu \mathrm{g})$, oxacillin $(1 \mu \mathrm{g})$, novobiocin $(5 \mu \mathrm{g})$, nalidixic acid $(30 \mu \mathrm{g})$, ceftizoxime $(30 \mu \mathrm{g})$, gentamicin $(30 \mu \mathrm{g})$, tetracycline $(30 \mu \mathrm{g})$ and ciprofloxacin $(5 \mu \mathrm{g})$ were tested. The isomer type of lactic acid was determined by using a DL lactate test kit (Boehringer).

The peptidoglycan structure of the cell wall of strain UCC $128^{\mathrm{T}}$ was determined by the DSMZ according to the method of Rhuland et al. (1955). The DNA G + C content of strain UCC $128^{\mathrm{T}}$ was determined by the DSMZ via a HPLC analytical method. DNA was purified on hydroxyapatite according to the method of Cashion et al. (1977) and was hydrolysed and dephosphorylated according to Mesbah et al. (1989). HPLC was performed in accordance with the protocol outlined by Tamaoka \& Komagata (1984). The G $+\mathrm{C}$ content was determined as described by Mesbah et al. (1989).

Genomic DNA was isolated from all four of the novel isolates according to the method of Sambrook et al. (1989) and was used as template for the amplification of a large portion of the 16S rRNA gene by PCR as described by Corsetti et al. (2005). DNA sequencing reactions were performed at MWG Biotech AG. To determine the phylogenetic position of strain $\mathrm{UCC} 128^{\mathrm{T}}$, the nearlycomplete 16S rRNA gene sequence was aligned with the corresponding gene sequences of other lactobacilli by using the CLUSTAL W program (Thompson et al., 1994). The $16 \mathrm{~S}$ rRNA gene sequence of the type strain of Bacillus subtilis was added to root the trees. Phylogenetic analysis and tree construction were performed by using the neighbourjoining method under Kimura's two-parameter substitution model (Kimura, 1980) and with the maximumparsimony method with MEGA4 software (Tamura et al., 2007). Phylogenetic trees were also constructed via the maximum-likelihood method by using PHYML software (Guindon \& Gascuel, 2003), which allows a general timereversible model to be used to accommodate rate variation among sites. Bootstrap values for each tree were calculated by resampling 100 times.

Levels of DNA-DNA relatedness were determined by the DSMZ between strain UCC $128^{\mathrm{T}}$ and L. mali DSM $20444^{\mathrm{T}}$.
DNA-DNA hybridization was performed as described by De Ley et al. (1970) with modifications according to the method described by Huß et al. (1983), by using a model Cary 100 Bio UV/Vis-spectrophotometer equipped with a Peltier-thermostatted $6 \times 6$ multicell changer and a temperature controller with in situ temperature probe (Varian).

Colonies of strains UCC128 ${ }^{\mathrm{T}}$, UCC125, UCC126 and UCC127 grown on MRS agar for 3 days at $30{ }^{\circ} \mathrm{C}$ were approximately $0.75-1 \mathrm{~mm}$ in diameter and appeared as smooth, circular, white colonies on the surface of the plates. Cells were rod-shaped, $0.5 \times 0.8-1 \mu \mathrm{m}$ in size, nonmotile and occurred singly, in pairs or in short chains. Cells were Gram-positive (data not shown). Carbohydrate fermentation profiles revealed the four novel isolates to be capable of producing acid from D-glucose, D-fructose, mannose, mannitol, methyl $\alpha$-D-mannoside, methyl $\alpha$-Dglucopyranoside, amygdalin, arbutin, salicin, cellobiose, maltose, sucrose and $\beta$-gentiobiose. The isolates were catalase-negative (Table 1). Aesculin hydrolysis was observed and no gas was produced from glucose. Growth was observed at 21 and $42{ }^{\circ} \mathrm{C}$, with optimal growth at $30{ }^{\circ} \mathrm{C}$; no growth occurred at 15 or $45{ }^{\circ} \mathrm{C}$. The strains were unable to grow at $\mathrm{pH} 3$, but could grow at $\mathrm{pH} 4$; in MRS the novel strains were able to grow at $\mathrm{pH} 8$ but not at $\mathrm{pH}$ 9. The isolates were able to grow in the presence of $4 \%$ $\mathrm{NaCl}$, but were unable to grow in $5 \% \mathrm{NaCl}$. The strains were sensitive to ampicillin, penicillin G, amoxicillin, trimethoprim, chloramphenicol, oxacillin, novobiocin, gentamicin, tetracycline and ciprofloxacin, but resistant to metronidazole, cephradine, nalidixic acid and ceftizoxime.

The peptidoglycan structure of strain $\mathrm{UCC} 128^{\mathrm{T}}$, as determined by the DSMZ, was identified to be of type Al $\gamma$, due to the presence of meso-diaminopimelic acid. $L$. mali DSM $20444^{\mathrm{T}}$ also possesses this type of peptidoglycan structure. The DNA G $+\mathrm{C}$ content of strain $\mathrm{UCC} 128^{\mathrm{T}}$ was $36.5 \mathrm{~mol} \%$, which falls within the range $(32-53 \mathrm{~mol} \%)$ reported for species of the genus Lactobacillus (Kandler \& Weiss, 1986).

Strains UCC128 ${ }^{\mathrm{T}}$, UCC125, UCC126 and UCC127 were found to share $100 \% 16 \mathrm{~S}$ rRNA gene sequence similarity, indicating that they should all be placed in the same species grouping. The closest relative to strain $\mathrm{UCC}_{128} 8^{\mathrm{T}}$ as revealed by $16 \mathrm{~S}$ rRNA gene sequence analysis was Lactobacillus sp. 88 (98\% similarity), an undescribed strain identified in a study of wine-associated LAB (Rodas et al., 2005). The closest recognized relative to $\mathrm{UCC}^{2} 28^{\mathrm{T}}$ was $L$. mali DSM 20444 ${ }^{\mathrm{T}}$ (Carr \& Davies, 1970), with $97 \% 16 \mathrm{~S}$ rRNA gene sequence similarity. According to Stackebrandt \& Goebel (1994), a similarity value of $97 \%$ or less with the closest relative may indicate that the isolate represents a novel species, rendering the determination of DNA-DNA relatedness values unnecessary. However, a more recent report suggests that DNA-DNA relatedness values should be determined for strains showing $16 \mathrm{~S}$ rRNA gene sequence 
Table 1. Differential phenotypic characteristics between strain UCC128 ${ }^{\top}$ and the closest related species in the genus Lactobacillus

Strains: 1, UCC128 ${ }^{\mathrm{T}}$ (strains UCC125, UCC126 and UCC127 gave identical results); 2, L. mali DSM 20444 ${ }^{\mathrm{T}}$ (data from Carr \& Davies, 1970); 3, L. satsumensis JCM $12392^{\mathrm{T}}$ (Endo \& Okada, 2005); 4, L. nagelii ATCC $700692^{\mathrm{T}}$ (Edwards et al., 2000); 5, L. algidus JCM 10491 ${ }^{\mathrm{T}}$ (Kato et al., 2000); 6, L. vini DSM 20605 ${ }^{\mathrm{T}}$ (Rodas et al., 2006); 7, L. animalis JCM 5670 ${ }^{\mathrm{T}}$ (Kandler \& Weiss, 1986); 8, L. murinus JCM 1717 ${ }^{\mathrm{T}}$ (Kandler \& Weiss, 1986); 9 , L. equi JCM $10991^{\mathrm{T}}$ (Morotomi et al., 2002). Strains 1-6: -, negative reaction; +, positive reaction; $\mathrm{v}$, variable; NA, no data available; $m \mathrm{DAP}$, mesodiaminopimelic acid. Strains 7-9: +, >90\% of strains positive; -, >90\% of strains negative; $\mathrm{d}, 11-89 \%$ of strains positive; NA, no data available. All strains were catalase-negative.

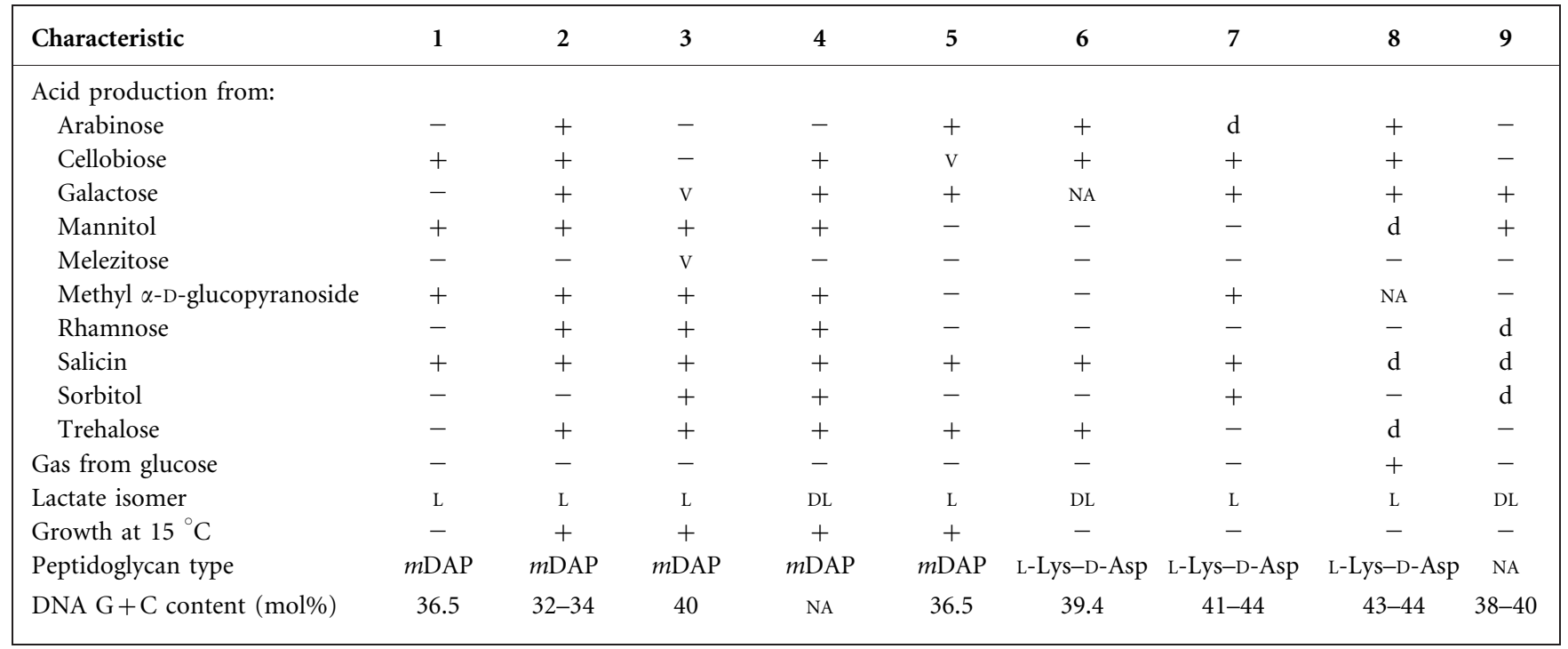

similarity of 98.7-99\% (Stackebrandt \& Ebers, 2006), to allow for more precise species classification. Levels of $16 \mathrm{~S}$ rRNA gene similarity were also calculated between strain UCC $128^{\mathrm{T}}$ and the type strains of other recognized species of the genus Lactobacillus, including Lactobacillus satsumensis (95\%), 'Lactobacillus mobilis' (95\%), Lactobacillus nagelii (95\%), Lactobacillus murinis (94\%), Lactobacillus algidus (94\%) and Lactobacillus animalis (94\%). Fig. 1 depicts the phylogenetic relationship between strain UCC $128^{\mathrm{T}}$ and its closest related species, resulting from alignments of their 16S rRNA gene sequences according to the neighbour-joining method. Similar tree topologies were obtained by using the maximum-parsimony and maximum-likelihood methods (see Supplementary Figs S1 and S2, respectively, in IJSEM Online).

DNA-DNA hybridization between $\mathrm{UCC}^{2} 28^{\mathrm{T}}$ and L. mali DSM $20444^{\mathrm{T}}$ revealed a level of relatedness of $39.4 \%$, well below the threshold value of $70 \%$ recommended by Wayne et al. (1987) for defining a bacterial species. Therefore, strain UCC $128^{\mathrm{T}}$ does not belong to the species L. mali. On the basis of the data presented here, we propose that strains

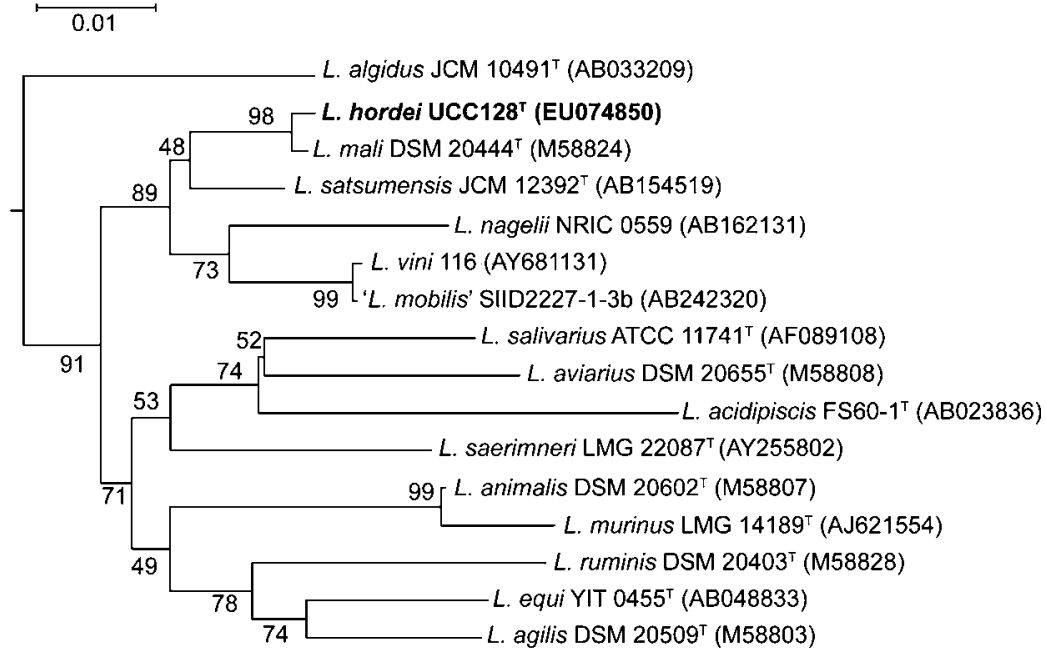

Fig. 1. Phylogenetic tree depicting the relationship between strain $\mathrm{UCC} 128^{\top}$ and its closest relatives as deduced from 16S rRNA sequence analysis. The tree was constructed by using the neighbour-joining method and approximately $1400 \mathrm{nt}$ of the 16S rRNA gene was used for sequence alignment. Bar, 0.01 nucleotide substitutions per site. 
UCC128 ${ }^{\mathrm{T}}$, UCC125, UCC126 and UCC127 represent a novel species of the genus Lactobacillus, for which the name Lactobacillus hordei sp. nov. is proposed.

\section{Description of Lactobacillus hordei sp. nov.}

Lactobacillus hordei (hor'de.i. L. gen. neut. n. hordei of/ from barley).

Cells are Gram-positive rods, approximately $0.5 \times 0.8-$ $1 \mu \mathrm{m}$ in length, non-motile, occurring singly, in pairs or in chains. Colonies are white, smooth and circular on MRS agar after 2 days incubation at $30{ }^{\circ} \mathrm{C}$ and measure 0.75 $1 \mathrm{~mm}$ in diameter. Facultatively anaerobic, catalasenegative and homofermentative. Optimum growth occurs at $30{ }^{\circ} \mathrm{C}$; no growth occurs at 15 or $45{ }^{\circ} \mathrm{C}$. Aesculin is hydrolysed. Growth is observed at $\mathrm{pH} 4$ and 8 , but not at $\mathrm{pH} 3$ or 9. Able to ferment D-glucose, D-fructose, mannose, mannitol, methyl $\alpha$-D-mannoside, methyl $\alpha$-D-glucopyranoside, amygdalin, arbutin, salicin, cellobiose, maltose, sucrose and $\beta$-gentiobiose, but not glycerol, erythritol, Darabinose, L-arabinose, ribose, D-xylose, L-xylose, adonitol, methyl $\beta$-xyloside, galactose, sorbose, rhamnose, dulcitol, inositol, sorbitol, $\mathrm{N}$-acetylglucosamine, lactose, melibiose, trehalose, inulin, melezitose, raffinose, starch, glycogen, xylitol, turanose, D-tagatose, D-fucose, L-fucose, D-arabitol, L-arabitol, gluconate, or 2- or 5-ketogluconate. The peptidoglycan structure is of $\mathrm{Al} \gamma$ type. The DNA G+C content is $36.5 \mathrm{~mol} \%$.

The type strain, UCC $128^{\mathrm{T}}\left(=\right.$ DSM $\left.19519^{\mathrm{T}}=\mathrm{LMG} 24241^{\mathrm{T}}\right)$, was isolated from malted barley. UCC125, UCC126 and UCC127, isolated from similar sources, are other strains of the species.

\section{Acknowledgements}

This work was supported by the Irish Government under National Development Plan 2000-2006. We would also like to thank Professor Hans Trüper for his assistance with the Latin translation of the species name.

\section{References}

Carr, J. G. \& Davies, P. A. (1970). Homofermentative lactobacilli of ciders including Lactobacillus mali sp. nov. J Appl Bacteriol 33, 768-774.

Cashion, P., Hodler-Franklin, M. A., McCully, J. \& Franklin, M. (1977). A rapid method for the base ratio determination of bacterial DNA. Anal Biochem 81, 461-466.

Corsetti, A., Settani, L., van Sinderen, D., Felis, G. E., Dellaglio, F. \& Gobetti, M. (2005). Lactobacillus rossii sp. nov., isolated from wheat sourdough. Int J Syst Evol Microbiol 55, 35-40.

De Ley, J., Cattoir, H. \& Reynaerts, A. (1970). The quantitative measurement of DNA hybridization from renaturation rates. Eur $J$ Biochem 12, 133-142.

Edwards, C. G., Collins, M. D., Lawson, P. A. \& Rodriguez, A. V. (2000). Lactobacillus nagelii sp. nov., an organism isolated from a partially fermented wine. Int J Syst Evol Microbiol 50, 699-702.
Endo, A. \& Okada, S. (2005). Lactobacillus satsumensis sp. nov., isolated from mashes of shochu, a typical Japanese distilled spirit made from fermented rice and other starchy materials. Int J Syst Evol Microbiol 55, 83-85.

Guindon, S. \& Gascuel, O. (2003). A simple, fast and accurate algorithm to estimate large phylogenies by maximum likelihood. Syst Biol 52, 696-704.

Hartnett, D. J., Vaughan, A. \& van Sinderen, D. (2002). Antimicrobial-producing lactic acid bacteria isolated from raw barley and sorghum. J Inst Brew 108, 169-177.

Hucker, G. J. (1921). A new modification and application of the Gram stain. J Bacteriol 6, 395-397.

Huß, V. A. R., Festl, H. \& Schleifer, K. H. (1983). Studies on the spectrophotometric determination of DNA hybridization from renaturation rates. Syst Appl Microbiol 4, 184-192.

Kandler, O. \& Weiss, N. (1986). Genus Lactobacillus Beijerinck 1901. In Bergey's Manual of Systematic Bacteriology, vol. 2, pp. 1209-1234. Edited by P. H. A. Sneath, N. S. Mair, M. E. Sharpe \& J. G. Holt. Baltimore: Williams and Wilkins.

Kato, Y., Sakala, R. M., Hayashidani, H., Kiuchi, A., Kaneuchi, C. \& Ogawa, M. (2000). Lactobacillus algidus sp. nov., a psychrophilic lactic acid bacterium isolated from vacuum-packaged refrigerated beef. Int $J$ Syst Evol Microbiol 50, 1143-1149.

Kimura, M. (1980). A simple method for estimating evolutionary rates of base substitution through comparative studies of nucleotide sequences. J Mol Evol 16, 111-120.

Mesbah, M., Premachandran, U. \& Whitman, W. B. (1989). Precise measurement of the $\mathrm{G}+\mathrm{C}$ content of deoxyribonucleic acid by highperformance liquid chromatography. Int J Syst Bacteriol 39, 159-167.

Morotomi, M., Yuki, N., Kado, Y., Kushiro, A., Shimazaki, T., Watanabe, K. \& Yuyama, T. (2002). Lactobacillus equi sp. nov., a predominant intestinal Lactobacillus species of the horse isolated from faeces of healthy horses. Int J Syst Evol Microbiol 52, 211-214.

O'Mahony, A., O'Sullivan, T., Walsh, Y., Vaughan, A., Maher, M., Fitzgerald, G. F. \& van Sinderen, D. (2000). Characterisation of antimicrobial producing lactic acid bacteria from malted barley. J Inst Brew 106, 403-410.

O'Sullivan, T. F., Walsh, Y., O'Mahony, A., Fitzgerald, G. F. \& van Sinderen, D. (1999). A comparative study of malthouse and brewing microflora. J Inst Brew 105, 55-61.

Rhuland, L. E., Work, E., Denman, R. F. \& Hoare, D. S. (1955). The behavior of the isomers of $\alpha, \varepsilon$-diaminopimelic acid on paper chromatograms. J Am Chem Soc 77, 4844-4846.

Rodas, A. M., Ferrer, S. \& Pardo, I. (2005). Polyphasic study of wine Lactobacillus strains: taxonomic implications. Int J Syst Evol Microbiol 55, 197-207.

Rodas, A. M., Chenoll, E., Macián, M. C., Ferrer, S., Pardo, I. \& Aznar, R. (2006). Lactobacillus vini sp. nov., a wine lactic acid bacterium homofermentative for pentoses. Int J Syst Evol Microbiol 56, 513-517.

Rouse, S., Sun, F., Vaughan, A. \& van Sinderen, D. (2007). Highthroughput isolation of bacteriocin-producing lactic acid bacteria, with potential application in the brewing industry. J Inst Brew 113, 256-262.

Sambrook, J., Fritsch, E. F. \& Maniatis, T. (1989). Molecular Cloning: a Laboratory Manual, 2nd edn. Cold Spring Harbor, NY: Cold Spring Harbor Laboratory Press.

Stackebrandt, E. \& Ebers, J. (2006). Taxonomic parameters revisited: tarnished gold standards. Microbiol Today 33, 152-155.

Stackebrandt, E. \& Goebel, B. M. (1994). Taxonomic note: a place for DNA-DNA reassociation and $16 \mathrm{~S}$ rRNA sequence analysis in the present species definition in bacteriology. Int J Syst Bacteriol 44, 846-849. 
Tamaoka, J. \& Komagata, K. (1984). Determination of DNA base composition by reversed-phase high-performance liquid chromatography. FEMS Microbiol Lett 25, 125-128.

Tamura, K., Dudley, J., Nei, M. \& Kumar, S. (2007). MEGA4: molecular evolutionary genetic analysis (MEGA) software version 4.0. Mol Biol Evol 24, 1596-1599.

Thompson, J. D., Higgins, D. G. \& Gibson, T. J. (1994). CLUSTAL W: improving the sensitivity of progressive multiple sequence alignment through sequence weighting, position-specific gap penalties and weight matrix choice. Nucleic Acids Res 22, 4673-4680.

Wayne, L. G., Brenner, D. J., Colwell, R. R., Grimont, P. A. D., Kandler, O., Krichevsky, M. I., Moore, L. H., Moore, W. E. C., Murray, R. G. E. \& other authors (1987). International Committee on Systematic Bacteriology. Report of the ad hoc committee on reconciliation of approaches to bacterial systematics. Int $J$ Syst Bacteriol 37, 463-464. 